most useless. We should much like, for the sake of our geological as well as entomological readers, to give a translation of his prefatory observations, which contain a synopsis of all that is yet known of fossil entomology, and also many useful observations directing us in the determination of the existence of insects without their actual presence ; and in methods for facilitating the discovery of collateral evidence of the same fact : to this however we may possibly return, as it is a subject replete with interest. The application of trivial names to such mutilated remains is a vain and hopeless endeavour to enlarge our knowledge of species, and can scarcely answer any end, especially when we reflect what nice discrimination is frequently required to determine recent species, in the best state of preservation; and in a fossil state the same individual species, from the variety of states of preservation in which it may come down to us, would be thus propagated into as many species, from their presenting no tangible means of identification. All therefore that we can reasonably hope for in fossil entomology is a knowledge of the genera peculiar to certain geological formations and their contemporaneous zoology and botany. Of course it will be understood that we exclude from this sweeping condemnation insects preserved in amber and copal, in which substances they usually retain their pristine perfection. We must however be thankful that this uninviting task has fallen into hands which can enliven with great interest a subject apparently so barren.

\title{
Transactions of the Berwickshire Naturalists' Club.
}

The unassuming Transactions of this locally useful Club, printed for private circulation among its members and their friends, has been kindly forwarded to us. The exertions of the Club are continued, and we now have the result of their labours during 1839 , commencing with the Annual Address of the President, the Rev. T. Knight, Vicar of Ford.-Next a " Notice regarding the Cessation of the Flow of the river Teviot" on 27th Nov. 1838; by Dr. Douglas of Kelso : which proves that it was occasioned by accumulation of ice.- "On the effects produced on Animal and Vegetable Life by the Winter of 1838 ;" by P. J. Selby, Esq: of Twizel House : a Paper very interesting to compare with the season in other parts of Britain and Ireland.- " Meteorological Observations made at the Abbey St. Bathon's, Berwickshire."- "On the Metamorphosis of Balanus punctatus of Montague;" by the Rev. T. Riddel, Fellow of Trinity College, Cambridge.- " A description of the Cephalopoda which inhabit the coast of Berwickshire;" by Dr. Johnston._- "On the Nests of the Fifteen-spined Stickleback, or Gasterosteus spinachia of Linnæus."- 
"Notice of a curious Aquatic Larva found in a water-jug at Twizel ;" by P. J. Selby, Esq. - "Case of Andrew Mitchel, aged 10 years, from whose nose Larvæ of a coleopterous Insect were discharged.""Notice of the Myliobates Aquila of Cuvier, or Eagle Ray of Yarrell;" by Dr. Johnston : a specimen has been taken in Berwick Bay."Contributions to the Flora of Berwickshire ;" by Mr. James Hardy. We have been much interested by the narratives of the periodical excursions of the Members of the Club. They present to our view a most delightful means of instructive intercourse and pleasing recreation, in which we see the clergy and members of the medical profession assisting their neighbours in the promotion of a love for the study of nature, and joining them in the investigation of the districts in which it is their lot to reside. The example is well worthy of imitation.

\section{PROCEEDINGS OF LEARNED SOCIETIES.}

\section{LINNAAN SOCIETY.}

Feb. 18.-The Lord Bishop of Norwich, President, in the Chair.

Mr. George T. Fox, F.L.S., exhibited a specimen of the Phrynosoma cornutum (Agama cornuta of Harlan) from Texas.

Mr. Cameron, A.L.S., presented a specimen of a new fern (Cibotium Baromez, J. Sm.) which has lately borne fructification, for the first time in this country, in the garden of the Birmingham Horticultural Society. A description of the plant by Mr. Westcott accompanied the specimen. The fern has been cultivated for some years in the gardens as the Agnus Scythicus or Vegetable Lamb (Polypodium Baromez, Linn.), but whether identical with the plant of Linnæus is a question still undetermined, as there happens to be no specimen in his herbarium, and the description alone is too meagre to settle the point. Mr. Westcott is however in possession of a specimen of a fern collected in Mexico by Mr. Ross, which closely resembles the plant of the gardens, and should they prove to be identical, all doubt will be removed as to the claims of the present plant to be regarded as the Baromez of Linnæus, which is a native of China.

The following is Mr. Westcott's description of the species :-

Rhizoma densely clothed with yellow woolly articulated hairs. Stipes about 7 feet high, roundish, of a dark reddish brown colour, more or less covered with tufts of woolly hairs near the base, naked for about half its height: upper part flexuous from the point where the pinnæ commence. Frond bipinnate; pinna alternate, ovate-lanceolate, acuminate, smooth, under surface glaucous, upper surface 


\section{$2 \mathrm{BHL}$ Biodiversity Heritage Library}

1840. "Transactions of the Berwickshire Naturalists' Club." Annals of natural history 5, 129-130. https://doi.org/10.1080/00222934009496781.

View This Item Online: https://www.biodiversitylibrary.org/item/19397

DOI: https://doi.org/10.1080/00222934009496781

Permalink: https://www.biodiversitylibrary.org/partpdf/21503

\section{Holding Institution}

Natural History Museum Library, London

\section{Sponsored by}

Natural History Museum Library, London

\section{Copyright \& Reuse}

Copyright Status: NOT_IN_COPYRIGHT

This document was created from content at the Biodiversity Heritage Library, the world's largest open access digital library for biodiversity literature and archives. Visit BHL at https://www.biodiversitylibrary.org. 